\title{
Lafaye, Jacques (2015). El islam en la mira: ocaso de la tolerancia y rebote del fanatismo. México: Colegio de Jalisco
}

Dr. Ricardo Fletes Corona

De la pluma del Dr. Jacques Lafaye ha salido un libro reciente, de tamaño pequeño pero de gran profundidad reflexiva, de actualidad indiscutible, de un tema que incumbe a las ciencias sociales y las humanidades en su conjunto pues toca de manera brillante, valiente y clara el tópico de El islam en la mira. Ocaso de la tolerancia y rebote del fanatismo. Con fecha de 2015 y bajo el sello editorial de El Colegio de Jalisco.

Si pensábamos que el siglo XXI nos traería un sistema planetario más equilibrado, de consenso y armonía, igualitario y tolerante, los trágicos acontecimientos nos revelan un mundo que parece haber retrocedido en su manera de resolver los conflictos, de esa manera nos plantea serios cuestionamientos como la "especie superior" de la naturaleza, nos llama a

revisar el papel de organismos internacionales pacificadores, a revisar el derecho internacional, en suma, exige ponernos frente al espejo como entes culturales globales y repensar nuestro presente y futuro humano; estamos poniendo en peligro el equilibrio la sustentabilidad del planeta por actuar predatoriamente, hemos acabado con varias especies y corremos el riesgo de hacerlo con nosotros mismos. Actuamos más como virus insaciables y el peso de la cultura, de la cual nos ufanamos nos distingue del resto de especies, no tiene la fuerza necesaria para cambiar de rumbo. Necesitamos entender cómo estamos como cultura, como culturas y apoyarnos en las ciencias sociales y humanas para retomar otro camino, este parece conducirnos a la extinción.

En esta tarea, el texto del Dr. Lafaye es de una ayuda importante. En 101 páginas, tres mapas y una generosa bibliografía en francés, inglés, español y alemán, nos expone de manera sintética pero abrumadora la complejidad de la relación conflictiva del llamado 
oriente medio y el occidente europeo; pero en realidad se trata de una disputa entre oriente y occidente, en donde lo religioso se cruza con lo político, lo económico, lo cultural, en suma, con lo social, creando una recomposición geopolítica que no es sencillo desentrañar adquiriendo, así, complejidad que solamente una mente privilegiada es capaz de arrojarnos claridad ante tal nudo gordiano.

El libro arranca de la matanza del personal de la revista satírica Charlie Hebdo, para enseguida explicarnos qué sentido tuvo ese acto, para unos justicia, para otros un acto de represión a la libertad de expresión. ¿Cómo entender e interpretar mejor tal hecho?, ahí inicia la generosa labor de exégesis del Dr. Lafaye, acudiendo a la interpretación de otros y la suya propia apoyada en acontecimientos históricos, a la develación de citas del Corán (y sus prescripciones para el Islam) y su análisis, al papel jugado por Francia y otras naciones occidentales en el oriente medio, a las cifras estadísticas de población musulmana migrante a Europa, reflexiona sobre la asimilación cultural y la diferencia que existe entre migrantes a Estados Unidos y a Francia.

De pronto nos es relativamente fácil entender por qué para un islamista radical morir en la yihad es un buen morir. Pero ello no explica la complejidad de la relación oriente-occidente y los antecedentes que llevan a describir y entender mejor que se trata de una relativamente joven pero larga historia de desencuentros (por decirlo de manera gentil) entre estas dos regiones/visiones/sistemas que hoy se enfrentan y confrontan, clamando justicia, gritando barbarie y en nombre de una u otra derramando sangre entre ambos bandos y quienes entre ellos se interpongan. Para complejizar más el asunto Rusia entra casi siempre ha estado en el escenario- de manera más directa en el escenario, en sus territorios o ex territorios también hay población que profesa el islam. Estados Unidos también está presente apoyando a unos $\mathrm{u}$ otros contendientes por el poder en los estados del mundo islámico. En este sentido los tres mapas que el autor elabora y agrega al final del texto, son de enorme ayuda para entender la problemática que nos ayuda a desentrañar.

Estamos frente a un texto de lectura obligada para los internacionalistas del derecho, de la política y geopolítica, de la paz y la guerra, vayaj, un texto que es básico para la cultura contemporánea, que nos ayuda a entender didácticamente una región que ha puesto en vilo al planeta entero, que da otro sentido a la idea de la globalización y que nos plantea el reto ineludible de comprender mejor los hechos sociales antes de opinar de manera superficial. El tema es complejo, 
el autor allana el camino de nuestra comprensión como suelen hacerlo los buenos maestros, al punto que nos provoca pensar seriamente sobre el futuro de la civilización, lo cual no es poca cosa.

Lafaye, Jacques

El islam en la mira: ocaso de la tolerancia y

Ficha rebote del fanatismo.

México: El Colegio de Jalisco, 2015.

ISBN: 978-607-8350-25-4

Bibliográfica 